\title{
Key audit matters in the auditor's reports on the example of European mining companies
}

\author{
Mariola MAMCARCZYK ${ }^{1}$, Lukasz POPLAWSKI ${ }^{2}$ and Pawet ZIENIUK ${ }^{3^{*}}$
}

Authors' affiliations and addresses:

${ }^{1}$ Department of Economics, Cracow University of Economics, Poland

e-mail: mariola.mamcarczyk@uek.krakow.pl

${ }^{2}$ Department of Local Government Finance,

Cracow University of Economics, Poland

e-mail: lukasz.poplawski@uek.krakow.pl

${ }^{3}$ Department of Financial Accounting, Cracow

University of Economics, Poland

e-mail: pawel.zieniuk@uek.krakow.pl

*Correspondence:

Paweł Zieniuk, Cracow University of Economics Department of Financial Accounting

Rakowicka Street 27

31-510 Cracow, Poland

tel.: (48) 12-293-52-36

e-mail: pawel.zieniuk@uek.krakow.pl

Funding information:

Cracow University of Economics

26/EFR/2020/POT

How to cite this article:

Mamcarczyk, M., Popławski, Ł. and Zieniuk, P. (2020). Key Audit Matters in the auditor's reports on the example of European mining companies. Acta Montanistica Slovaca, Volume 25 (4), 453 465

DOI:

https://doi.org/10.46544/AMS.v25i4.02

\begin{abstract}
Implementation of changes to the scope of statutory auditor's reporting has become a starting point to take the issue into consideration in the international literature on possibilities to limit an audit expectation gap i.e. an information expectation gap with regard to an audit. Its partial limitation has become possible owing to a new audit reporting which should be a valuable source of independent information for stakeholders with Key Audit Matters (KAMs). They are the issues most significant while auditing a financial statement of a given company for a current period. The higher number of KAMs revealed by a statutory auditor may suggest a higher number of problem areas in an audited company's activity.

This paper aims to determine the factors that influence the number of KAMs that auditors disclose in their audit reports on the financial statements of European mining companies. Sixty-two companies from the mining industry, listed on European stock exchanges and taken into consideration on the ORBIS basis, were taken for the research sample. The content analysis included financial statements and statutory auditors' reports for the year 2019. The authors formulated the main hypotheses, according to which: The number of KAMs reported in the auditor's reports from auditing the financial statements of mining companies is positively associated with the size of the audited company (H1) and the amount of the audit fee (H2).

The research on the practice of KAM reporting allowed to identify the most problematic areas existing in the companies of the mining branch, which include: investments in related entities, property and tangible assets, provisions and contingencies. The verification of the suggested research hypotheses allowed to state that in the case of the companies of the mining sector, the higher number of reported KAMs is not connected with the number of these companies' assets, but the scale of their activity, expressed with the number of incomes. The relationship between the number of KAMs and an amount of an audit fee was also confirmed. The added value of the conducted research of KAM reporting practice is a possibility to use the results in the practice of the activity of mining companies. The review of the most frequent KAMs provides a general opinion on specific problems existing, according to the authors, in companies operating businesses in this branch. The authors notice limitations of the research resulting from the adopted research sample and a need to conduct next studies, which will be connected with the in-depth analysis of the scope and the type of disclosed KAMs as well as their changes in the next reporting periods.
\end{abstract}

\section{Keywords}

key audit matters, audit expectation gap, financial audit, mining companies, accounting, statutory auditor, auditor's reports, financial statements. 


\section{Introduction}

In 2015 the International Auditing and Assurance Standards Board (IAASB) introduced changes in the International Auditing Standards (IAS), the aim of which was to increase the informative value of reports from statutory auditors' audit. The implemented IAS 701 obliged statutory auditors to report Key Audit Matters (KAM), i.e. issues, which according to a statutory auditor's professional opinion, were the most significant while examining a financial statement for a current period. The changes to statutory auditors' reporting intend to satisfy rising information expectations of recipients of financial statements. The obligation to report KAMs by a statutory auditor leads to the presentation of a wider context of statutory auditors' work in order to analyse their conclusions more effectively. The introduction of the obligation of reporting KAMs results from the implementation of Directive No. 537/2014 (the European Parliament, 2014), introducing greater transparency in statutory auditors' reports.

Reporting KAMs in statutory auditors' reports on the basis of the audits of listed companies, which are made publicly available and published on websites of these entities, enabled to conduct numerous empirical studies, the examples of which can be found in the international literature of the subject. The analysis of the empirical material usually focuses on the discussion of key problems, which are seen by a statutory auditor while auditing listed companies and procedures of the audit taken as a reaction to a risk existing in the stated areas. The part of authors also tries to define determinants influencing the number of KAMs disclosed by statutory auditors. These studies usually concentrate on companies from a chosen country or constituting chosen stock exchanges indexes.

The authors' goal was to do empirical research aiming at the presentation of KAMs, existing in listed companies operating in a chosen specific sectors of the economy and the determination of determinants of a number of reported KAMs. Sixty-two companies were accepted for the research sample, operating in the mining industry, listed in the main European stock exchanges, included in the ORBIS database. The accepted research sample size is comparable with the previous empirical research done to define determinants of a number of reported KAMs.

The method of content analysis was used in the empirical research. The complete versions of financial statements and auditors' reports of the examined individual companies for 2019 were empirical material. The data published in the ORBIS database were also used. The quantitative research methodology with the support of the Statistica software was employed. The Poisson regression analysis was applied to confirm the statistical relationship.

The results of the previous research indicate that a positive association exists between the audit fee and the number of KAMs disclosed (Pinto and Morrais, 2018; Oghuvwu and Orakwue, 2019). Moreover, the relationships between a number of disclosed KAMs and the size of entities were proved (Loew and Mollenhauer, 2019; Pinto and Morais, 2018; Karmańska, 2020). In order to verify if these relationships exist in the case of the companies of the mining industry operating in various European countries, the following hypotheses were formulated: The number of KAMs reported in the auditor's reports from auditing the financial statements of mining companies is positively associated to the amount of the audit fee (H1) and the size of the audited company (H2). The additional variables explaining a number of reported KAMs were also suggested in the regression model, such as the number of operating segments of an examined entity, the strength of reporting and auditing standards or an auditor's category conducting an audit of a financial statement.

The article presents a review of the international literature together with the most important conclusions from the empirical research concerning the practice of KAMs reporting. The next part depicts the construction of the own audit, its results and the discussion of the obtained results. The conducted study of the practice of KAMs reporting, taking the companies of the mining sector from various European countries into consideration, gives an opportunity to present specific problems of this sector, the essential ones for the auditor auditing a financial statement. The research results contribute to bridging the identified audit gap. They allow identifying the most important problems occurring during the audit of financial statements of the companies of this sector. They can also contribute to a better understanding of the process of an audit and its results in the form of an auditor's report by recipients of financial reports, investors and other stakeholders.

\section{Theoretical background and literature review}

The changes to the provisions of law with regard to reporting by statutory auditors from auditing financial statements increased the requirements concerning the effects of this process. There is still a belief that the socalled audit expectation gap exists between the expectations of the users of financial statements regarding statutory auditors' obligations and results of their work made available to the public in the form of an audit report. The term audit expectation gap was formulated in the international literature of the subject (Lee, Ali and Gloeck, 2009). The main cause of the existence of a gap are various beliefs on statutory auditors' obligations and on the scope and the informative value of an audit report (Koh and Woo, 1998). The growing stakeholders' 
expectations do not take the specificity of statutory auditors' work into consideration; those who auditing financial statements use methods of randomisation and sampling, and the term of significance is essential in their work. In practice, however, it is not possible to detect all incorrectness. In case they are insignificant, their detection would be irrational if only because of the costs of the audit incommensurable to the found failures (Pfaff, 2007).

Whereas, the users of financial statements expect that an audit of financial statements will guarantee detection of any breaches and incorrectness (Gupta, 2005), and statutory auditors should also interpret financial statements in a way that would allow stakeholders to make a decision on investing in the entity (Salehi and Rostami, 2009). The following factors are given as the reasons for the existence of an audit expectation gap in the literature (Ebimobowei, 2010):

- a probabilistic nature of an audit,

- ignorance, naivety and unjustified expectations of society, stakeholders,

- evolutionary development of control obligations,

- lack of technical competence and imperfection of communication with an auditor,

- lack of full independence of assurance service provision.

An analysis and evaluation of a process of a financial statement audit by stakeholders is made difficult by the lack of possibilities of access to working papers elaborated by a statutory auditor during the audit. A statutory auditor has to ensure its confidentiality and inaccessibility for persons from outside the authorised entity, on whose behalf the audit is conducted. Therefore, an audit report stays the only communication tool of a statutory auditor with recipients of financial statements of an audited entity. Its extended version, complemented by the list of key audit matters and their description, can contribute to readers' better understanding of obligations imposed on entity management and also on auditors (Aljaaidi, 2009). However, it is still a problem if disclosures with regard to key audit matters really contribute to the understanding of an audit process of financial statements by stakeholders and if they fill in an audit expectation gap. The belief can be found in the literature of the subject, according to which a limitation of an audit expectation gap is possible by increasing the number of standards binding in the area of audit and accountancy (Saeidi, 2012). Thus, the implementation of the International Standard on Auditing 701 (IAS 701), introducing an auditor's responsibility for reporting KAMs, can be interpreted as a pursuit of a partial bridge of an audit expectation gap.

The objective of the presentation of KAMs in an audit report is to increase the informative value of a statutory auditor's report by providing greater transparency of a conducted audit (IAS 701). The standard also emphasises that the presentation of KAMs provides intended users of a financial statement with additional information. Furthermore, it helps them comprehend matters that, according to a statutory auditor's professional opinion, were the most significant during an audit of a financial statement.

The standard defines key audit matters as the matters which, according to a statutory auditor's professional opinion, were the most significant during an audit of a financial statement for a current period (IAS 701, § 8). They are selected from the matters presented to the supervising persons by a statutory auditor.

To establish the matters requiring significant attention, a statutory auditor takes the following into account:

- areas of an estimated higher risk of an essential distortion,

- important beliefs concerning the areas in financial statements which required an important opinion of an entity manager, including accounting estimates which were identified as the ones with the high estimation uncertainty,

- the effect of significant occurrences or transactions for the audit which happened during the period.

Each KAM established in this way is described by a statutory auditor with the use of an appropriate subheading in the separate section of an audit report. The description of KAM means to explain why the matter was considered to be one of those most important ones during the audit, and in connection with this fact, it was defined as the key one and how this matter was referred to during the audit. It should be emphasised that disclosure of key audit matters is not a substitute to express a modified opinion in the audit statement, i.e. to formulate explanations and restrictions by statutory auditors.

The number of KAMs that a statutory auditor should identify and disclose was not suggested in the standard IAS 701 or in other guidelines used by statutory auditors in their work. Consequently, establishing the number of KAMs reported in the audit statement depended on a statutory auditor's professional opinion. The higher number of disclosed KAMs can suggest the existence of a bigger number of problem areas in the activity of an audited company. Next, the analysis of types of KAMs reported by a statutory auditor can provide a general view of specific problems existing in companies running a business in a given branch. In the authors' opinion, it is a major reason for undertaking empirical research in this scope.

The research results of which are presented in the international literature of the subject concentrate on establishing which key audit matters are identified by statutory auditors in the audit process. The relationships between a number of disclosed key audit matters and the type of audit company conducting an audit are checked. 
The authors acknowledge that the most frequent descriptions of key audit matters reported in statutory auditors' statements are the most vital in the evaluation process of a risk of an essential distortion.

The research done on the sample of the companies listed in the stock exchanges in Great Britain, France and Holland showed a relationship between the number of reported key audit matters of the audit and the size of the company, profitability, the amount of the fee for the audit of financial statements and the number of segments on the market where the entity does a business (Pinto and Morais, 2019). Depending on the accepted research sample, the influence of individual factors on the results of empirical research usually has the same direction, but this impact is not always statistically important. The studies where the entities of the financial sector in the stock exchange in Nigeria were the research sample showed a positive and significant relationship between the fees for the audit and the number of the disclosed KAMs, whereas the size of the company showed an insignificant positive relationship (Oghuvwu and Orakwue, 2019). The similar research realised with the sample of the entities from the banking sector of the chosen European countries proved that the determinants of the number of the disclosed key audit matters are the size of the entity, the obtained results, the profit management, the business area and the audit entity conducting an audit (Loew and Mollenhauer, 2019).

The most often used KAMs, reported in the statutory auditors' statements auditing the Polish listed companies included the areas such as: estimation of impairment losses on financial assets, recognition of revenues from the sale, disclosure of claims, disputes and contingent liabilities, as well as settlement of deterred income tax assets (Kutera, 2019). The studies by K. Natkaniec (2020), conducted in the companies of the construction sector, proved that the most often reported key audit matters include: incomes from the sale, impairment of fixed assets, reserves, claims, disputes and contingent liabilities, as well as a continuation of activity (a liquidity risk). The auditors' statements auditing consolidated financial statements published in 2018 were analysed. B. Iwanowicz (2019) demonstrated that the most often used KAM categories in Polish companies included incomes, fixed assets and intangible assets, covering in total $61 \%$ of the studied sample of 156 companies. The comparative studies on the research sample of the companies listed in the stock exchanges in London and Warsaw proved that the reported KAMs do not differ significantly among the listed companies in the countries accepted for the sample (T. Iwanowicz, 2019).

The auditor's category auditing a financial statement, as a factor that can influence a number of reported KAMs, is connected with the division of auditing companies into the entities constituting the so-called BIG4 (Deloitte, EY, KPMG, PwC) and other auditing entities. The studies done on the listed companies from Croatia showed statistically essential differentiation between the number of KAMs disclosed by the auditors from BIG4 (the average of $1.7 \mathrm{KAM}$ ) and other auditors (the average of $1.1 \mathrm{KAM}$ ) representing smaller auditing entities (Tusek and Jezovita, 2018). However, the results of the research on the Polish listed companies demonstrated that there is a negative correlation between BIG 4 auditors and the number of KAMs (Karmańska, 2020). The type of auditing entities was also taken into consideration in the research done by Sierra-Garcia, Gambetta, Garcia-Benau and Orta-Peraz (2019). The results of the research show that Deloitte, EY and KPMG tend to report fewer entity-level-risk KAM than PwC, while KPMG and BDO report fewer account-level-risk KAM than PwC.

Therefore, on the basis of the analysis of the previous research available in the literature, a set of factors can be distinguished, which are most often taken into account as the determinants of the number of key audit matters. They were taken into consideration while constructing the elaborated model aiming at the identification of the determinants of the number of KAMs concerning the companies of the examined sector.

\section{Research design}

The companies listed in the main European stock exchanges were taken for the research sample, taken into consideration in the ORBIS database. In connection with the branch character of the study, the companies doing business in one of the following areas were exclusively accepted for the sample:

- hard coal and brown coal production,

- exploitation of oil and natural gas,

- mining of mineral ores,

- other mining and excavation.

The inactive companies and the companies which did not disclose financial statements and statutory auditors' reports to the public were rejected from the initial sample of 248 companies. The random selection with the constant sampling interval was applied among the other entities. Thus, the selection of the companies to the sample meets the conditions of a random selection. The final research sample consisted of 62 companies for which the analysis of the content provided in the statements was done. The accepted research sample should be considered as comparable in terms of the number with the research samples accepted in the international studies, which amounted for the chosen research to 93 (Pinto and Morais, 2018), 120 (Tusek and Jezovita, 2018), 100 (Sierra Garcia, Gambetta, Garcia-Benau and Orta-Peraz, 2019), 49 (Karmańska, 2020). Nevertheless, it should 
be stressed that the vast majority of international empirical research quoted in this paper was done on the companies of a lot of different branches.

In order to present the received results concerning the number and types of KAMs more clearly, their aggregation was used to create the following groups:

- acquisition,

- adoption of new accounting and reporting standards,

- cost recognition,

- credits and loans,

- financial instruments,

- first-year audit,

- going concern,

- goodwill and intangible assets,

- inventory,

- investments,

- investments in related entities,

- legal problems,

- property and tangible assets,

- provisions and contingencies,

- receivables and allowances,

- revenue recognition,

- taxation.

The KAMs disclosed in the statutory auditors' reports were classified into the main groups in order to present the collective summary of the most often existing problems of the audit of the companies in the mining sector. Assigning KAMs to the collective categories is common in the audits conducted by the leading auditing entities and the organisations gathering specialists in the field of finances and accounting (for instance, ACCA, 2018; Deloitte 2018; KPMG 2017).

The financial statements and the statutory auditors' reports were also a source of the data, such as an amount of a fee for an audit of a financial statement or a number of operating segments reported by an audited entity. The other data characterising the audited entities, such as a scale of operations measured by a number of total assets and annual incomes or elementary indicators of the financial analysis, were taken from the ORBIS database.

The collected data became a basis of the construction of the regression model, identifying the determinants of the number of the disclosed KAMs by the statutory auditors auditing the financial statements of the companies in the mining sector.

In order to verify the statistical hypotheses, the following explanatory variables were adopted for regression analysis purposes:

$\mathrm{X} 1$ - natural logarithm of the total assets

$\mathrm{X} 2$ - natural logarithm of the sum of annual incomes

$\mathrm{X} 3$ - proportion of an audit fee to total assets

$\mathrm{X} 4$ - number of reported operating segments

$\mathrm{X} 5$ - strength of reporting and auditing standards

$\mathrm{X} 6$ - auditor's category conducting an audit of the financial statement

$\mathrm{X} 7$ - return on equity ROE

$\mathrm{X} 8$ - pre-tax gain or loss

$\mathrm{X} 9$ - solvency ratio

The choice of the explanatory variables for the authors' linear regression model is motivated by a will to confirm the results of the previous research on the sample of the companies doing business in the specific sector of the economy - the mining industry. The goal of the research is to verify the main hypotheses: The number of KAM reported in the auditor's reports from auditing the financial statements of mining companies is positively associated with the size of the audited company (H1) and the amount of the audit fee (H2). Taking the other explanatory variables into account in the model will allow identifying other possible determinants of the number of the disclosed KAMs in the companies of the audited sector, thus giving a possibility to compare the obtained results with the results of the previous research.

The natural logarithms of the total assets (X1) and the annual incomes (X2) were adopted as the variables representing the size of the entity. The adoption of the above explanatory variables for the model results from the expected relationship according to which a bigger client whose financial statement is subject to an audit by a statutory auditor, a bigger number of the key audit matters. The logarithm was applied to normalise the features 
characterised by a big range (Goodwin-Stewart and Kent, 2006; Prawitt, Sharp and Wood, 2011; Sierra Garcia, Gambetta, Garcia-Benau and Orta-Peraz, 2019).

The statutory auditors' high fee can show a more complicated process of an audit. Therefore, the opinion can be found in the literature that a higher fee contributes to a more accurate process of an audit and an increased number of audit procedures. It may contribute to a higher number of possible disclosures of KAMs. The results of the research indicate that the amount of audit fees is positively connected with the level of strategic and operational risk (Yang, Yu, Liu and $\mathrm{Wu}, 2018$ ). Thus, there is an assumption that there should be more problematic issues at the higher level of risk. Nonetheless, one should also realise that a fee for an audit of financial statements is the main source of incomes of the auditing companies, which can result in the decrease in the statutory auditors' independence. If disclosure of KAMs is not accepted by an audited company that provides a high fee for an audited company, a statutory auditor may face an ethical dilemma in this situation. Owing to the above reasons, an amount of a fee for an audit of a financial statement was adopted for the regression model. The proportion of an audit fee to total assets of an audited company was adopted as an explanatory variable (X3). This solution is patterned on the previous empirical research (for example, Morais and Pinto, 2018; Ferreira and Morais, 2019).

The higher number of reported operating segments (X4) can show bigger complexity and a developed structure of an enterprise, which can cause the existence of a higher number of problematic issues in its business. The more complex structure is, the more types of risk which an entity is exposed to. The complexity of an enterprise is most often expressed with the number of reported operating segments (Bedard, Hoitasch and Hoitasch, 2008; Markanian and Parbonetti, 2007; Morais and Pinto, 2018).

Strength of reporting and auditing standards (X5) can contribute to the increase in precision of an audit process and identification of a higher number of problem areas by statutory auditors. Inaccuracy of standards and their weak strength can contribute to a choice of solutions which are a client's preferences (compare, for instance, Mayhew, Schatzberg and Sevcik, 2011). The indicator of standard strength used as an explanatory variable is given to the public by the World Economic Forum, within the research of The Global Competitiveness Report (Schwab, 2018). The index value is calculated for each country, and it takes the values from 1 to 7.

The explanatory variable X 6, representing an auditor's category conducting an audit of a financial statement, is a zero-one variable, taking a value "1" for big international auditing entities (Deloitte, EY, KPMG, $\mathrm{PwC}$ ) or " 0 " for other entities authorised to audit financial statements. The choice of the variable was based on the common classification of auditing entities conducting an audit of financial statements into two groups, which refers to the previous research (Tuek and Jezovita, 2018; Sierra Garcia, Gambetta, Garcia-Benau and Orta-Peraz, 2019; Karmańska, 2020) and the common view, dominating among the professional accountants and the persons conducting audits of high-level standardisation of audit procedures and working papers developed during the audit in big international auditing entities.

The adoption of the indicators of return on equity ROE (X7), pre-tax gain or loss (X8) and solvency ratio (X9) as additional control variables was based on the intention to confirm or contradict a common belief, according to which the higher number of problem areas exist in the entities characterised by lower profitability and solvency or obtaining lower financial results.

\section{Results}

The analysis of the content of the statutory auditors' reports concerning the audit of 62 entities of the mining sector allowed to identify $172 \mathrm{KAMs}$, which gives on average 2,77 KAMs per report, the minimum was 1 and maximum 7 KAMs (Fig. 1).

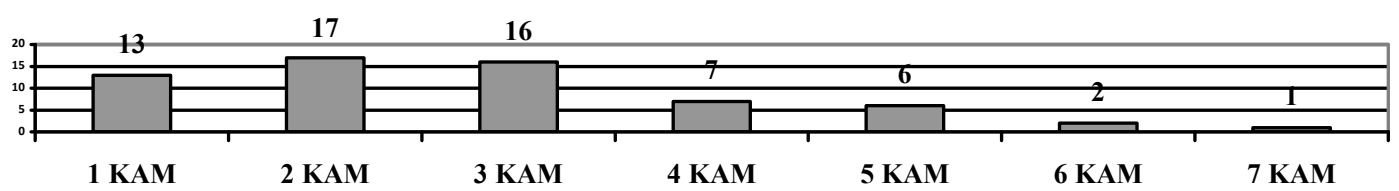

Fig.1. Distribution of the number of reported KAMs in the companies of the research sample

Figure 2 presents the collective summary of the number of identified KAMs in the sample of the companies of the mining branch in the division into the individual groups. The most frequently reported KAMs included: investments in related entities, property and tangible assets, provisions and contingencies. 


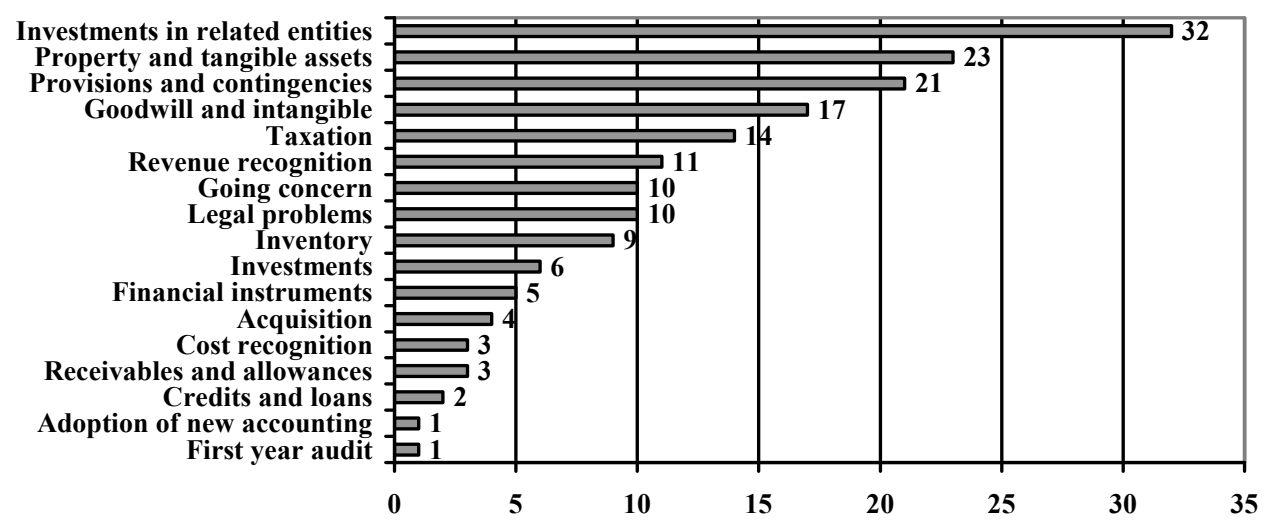

Fig.2. Number of the reported KAMs in the individual problem areas for the companies of the research sample

The variables in this study consisted of nine independent variables and one dependent variable. The dependent variable (Y) is the number of reported KAMs in auditors' reports. To understand the characteristics of the variables in terms of the minimum value, maximum, average and standard deviation, the descriptive statistical data is presented in Tab. 1 .

Tab. 1. Descriptive statistics

\begin{tabular}{c|cccc} 
VARIABLE & Minimum & Maximum & Mean & Std. Deviation \\
\hline Y & 1 & 7 & 2,77 & 1,45 \\
\hline X1 & 8 & 19,7 & 14,04 & 3,19 \\
\hline X2 & 2,59 & 19,54 & 12,60 & 0,57 \\
\hline X3 & 0,000004 & 0,014 & 0,0012 & 1,68 \\
\hline X4 & 1 & 8 & 3,06 & 0,48 \\
\hline X5 & 4,3 & 6,1 & 5,58 & 0,48 \\
\hline X6 & 0 & 1 & 0,65 & 54,49 \\
\hline X7 & $-360,31$ & 60,17 & 0,14 & 4490312 \\
\hline X8 & -3201000 & 22685600 & 1766978 & 26,61 \\
\hline X9 & $-28,15$ & 98,78 & 57,28 & \\
\hline
\end{tabular}

The analysis method used in this research is the Poisson regression analysis. The choice of the method is owing to the lack of meeting the assumption of the normal distribution for the explanatory variable $\mathrm{Y}$ (the number of the disclosed KAMs), which was checked with the use of the Shapiro-Wilk test. The use of the Poisson regression model can be found in numerous similar empirical research (for instance, Pinto and Morais, 2018, Kitiwong and Srijunpetch, 2019; Ghosh, 2011)

Tab. 2. Results of Poisson regression analysis

\begin{tabular}{|c|c|c|c|c|}
\hline VARIABLE & Estimate & Std. Error & $\mathrm{z}$ value & $\operatorname{Pr}>|z|$ \\
\hline $\mathrm{X} 1$ & $-1.00 \mathrm{e}-02$ & $1.236 \mathrm{e}-01$ & -0.081 & 0.935 \\
\hline $\mathrm{X} 2$ & $6.195 \mathrm{e}-02$ & $8.163 \mathrm{e}-02$ & 0.759 & 0.448 \\
\hline X3 & $-8.468 \mathrm{e}+01$ & $9.354 \mathrm{e}+01$ & -0.905 & 0.365 \\
\hline X4 & $-6.340 \mathrm{e}-03$ & $4.956 \mathrm{e}-02$ & -0.128 & 0.898 \\
\hline X5 & $1.705 \mathrm{e}-01$ & $1.703 \mathrm{e}-01$ & 1.001 & 0.317 \\
\hline X6 & $-5.655 e-02$ & $2.215 \mathrm{e}-01$ & -0.255 & 0.798 \\
\hline X7 & $-3.046 \mathrm{e}-03$ & $3.157 \mathrm{e}-03$ & -0.965 & 0.335 \\
\hline $\mathrm{X} 8$ & $-1.123 e-08$ & $2.189 \mathrm{e}-08$ & -0.513 & 0.608 \\
\hline X9 & $2.053 e-03$ & $3.764 \mathrm{e}-03$ & 0.546 & 0.585 \\
\hline const. & $-5.339 \mathrm{e}-01$ & $1.392 \mathrm{e}+00$ & -0.384 & 0.701 \\
\hline
\end{tabular}


We checked if the distribution of the explanatory variable $\mathrm{Y}$ is the Poisson distribution. Probability of being drawn from the Poisson distribution: 0.193. There were no grounds to reject the assumption that the Y variable has the Poisson distribution. The Poisson regression analysis was performed with the use of Statistica software. The results of the analysis are presented in Tab. 2.

The results of the Breusch-Pagan test illustrate heteroskedasticity of the residuals (BP: 16.563; df: 9; pvalue: 0.0565. However, the used Durbin-Watson test depicts the correlation of the residuals. Thus, the generalised least squares method for the exponential model was adopted. The results of the regression analysis are presented in Tab. 3 .

\begin{tabular}{|c|c|c|c|c|}
\hline VARIABLE & Value & Std. Error & t-value & $\mathrm{p}$-value \\
\hline $\mathrm{X} 1$ & -0.00989 & 0.10256 & -0.0964467 & 0.9235 \\
\hline $\mathrm{X} 2$ & 0.05365 & 0.06453 & 0.8313851 & 0.4096 \\
\hline $\mathrm{X} 3$ & -87.44656 & 34.84973 & -2.5092466 & 0.0153 \\
\hline $\mathrm{X} 4$ & 0.00633 & 0.04211 & 0.1502272 & 0.8812 \\
\hline $\mathrm{X} 5$ & 0.18870 & 0.15245 & 1.2377893 & 0.2214 \\
\hline X6 & 0.00524 & 0.19943 & 0.0262584 & 0.9792 \\
\hline $\mathrm{X} 7$ & -0.00340 & 0.00157 & -2.1687925 & 0.0347 \\
\hline $\mathrm{X} 8$ & 0.00000 & 0.00000 & -0.9296394 & 0.3569 \\
\hline X9 & 0.00083 & 0.00302 & 0.2743227 & 0.7849 \\
\hline const. & -0.63977 & 1.16579 & -0.5487900 & 0.5855 \\
\hline
\end{tabular}

For the purposes of verification of the statistical hypotheses, the significance level of $\alpha=0.05$ was adopted. The obtained results allow us to state the statistically significant relationship between the number of the reported KAMs and the amount of the audit fee (X3). The rejection of the next variables from the model allows to state that the best estimation is in the model with one explanatory variable (X2). The done Breusch-Pagan test and the Durbin-Watson one depicted heteroskedasticity and correlation of the residuals. It was decided again to adopt the generalised least squares method for the exponential model, receiving the better-adjusted $\operatorname{model}: \log (\mathrm{Y})=$ $0.42964+0.04525 * \mathrm{X} 2$. The results of the regression analysis for this model was presented in Tab. 4 .

\begin{tabular}{c|cccc}
$\begin{array}{l}\text { Tab. 4. Results of the Poisson regression analysis with the use of the generalised least squares method of for the exponential model } \\
\text { VARIABLE }\end{array}$ & Value & Std. Error & t-value & p-value \\
\hline X2 & 0.0444790 & 0.01355525 & 3.281313 & 0.0017 \\
\hline const. & 0.3138959 & 0.17223196 & 1.822519 & 0.0734 \\
\hline
\end{tabular}

The H1 hypothesis, according to which the number of the reported KAMs in the statutory auditor's report from the audit of the financial statements of the companies of the mining branch presents a statistically significant dependence on the size of the audited entity, was confirmed only partly. No significant dependence was found between the number of KAMs and the size of the entity expressed with the natural logarithm of the total assets (X1). There is a dependence between the number of KAMs and the size of the entity expressed with the natural logarithm of the total of annual incomes (X2). The H2 hypothesis was also assumed, according to which the number of the reported KAMs in the statutory auditor's report from the audit of the financial statements of the companies of the mining branch presents a statistically significant dependence on the number of fees for the audit of the financial statements.

\section{Discussion}

The average number of the identified KAMs in the companies of the mining sector amounting to 2.77 allows comparing with the studies carried out on the samples of the companies from other sectors of the economy and the studies which did not take belonging of the companies to the branch into consideration. For instance, the average number of KAMs amounted to 4.4 in the banking sector (Accountancy Europe, 2018), and from 1.9 in the industrial sector to 3.9 in the telecommunications sector (ACCA, 2018). In the case of the companies from various branches, the average number of KAMs amounted to about 2.8 according to the research of the auditing company KPMG (2017), 3.2 according to the research of the Deloitte company (2018). Therefore, the average number of the key problem areas identified by the statutory auditors auditing the companies of the mining sector is comparable with the average for the companies without the analysis of the belonging to the branch. 
The assignment of the identified KAMs to the groups separated owing to the type of the reported problem allows to state that the most often existing types of KAMs in the companies of the mining sector differ significantly from the results of the previous research. The highest number of the disclosed KAMs in the areas such as investments in related entities, property and tangible assets, provisions and contingencies can be, in the authors' opinion, explained with the specificity of the mining branch. The companies of this branch usually operate within the capital groups where there are numerous related entities. In order to do business, they need fixed assets, considerable both quantitatively and valuably. What is more, the creation of the reserves of significant value (such as the reserves for mining damage, the reserves for fringe benefits, the reserves for restructuring) is natural for the companies of the mining branch. It should be emphasised that none of the three groups of the most frequently existing KAMs in the companies of the research sample did not appear among the results of the previous research. Karmańska (2020), carrying out the research on the companies of the construction sector, states that revenues, going concern and impairment of assets, especially of goodwill, belong to the most often existing KAMs. Additionally, in the case of the studies done without the branch differentiation (Kutera, 2019; B. Iwanowicz, 2019) among 3 most often existing KAMs, none of the identified ones appears in the sample. The studies conducted on the bigger research samples by the leading auditing firms also present other sets of the most often occurring KAMs. The following are in the study by KPMG (2017): goodwill and related CGU assets, revenue and taxation. According to Deloitte (2018), they include goodwill and intangible assets, revenue recognition, accounts receivable and loans. Only in the case of the research of the ACCA organisation (2018), asset impairment (other than goodwill) is mentioned among the most often groups of the reported KAMs. Revenue and allowance for doubtful debt are the next two categories.

The set of the typical determinants of the number of the reported KAMs, resulting from the analysis of the international literature of the subject, was only partly confirmed in the accepted research sample of the companies of the mining sector.

The size of the company expressed by the sum of the annual incomes can be treated as a determinant of the key audit matters. It differs the obtained results from the part of the previous research (Pinto and Morrais, 2018; Loew and Mollenhauer, 2019; Karmańska, 2020). Thus, it should be mentioned that in the case of the analysed companies of the mining sector, the bigger number of the problem areas disclosed by the statutory auditors is not connected with the amount of the property of these companies, but the scale of their activity. In the authors' opinion, this is the sum of incomes which is the best indicator of the size of the company as the higher incomes, especially of the high diversity of their sources, can be connected with the higher level of risk in the company and contribute to the existence of the problem areas from the point of view of accounting and reporting.

Similarly to the part of the previous international research (for example, Pinto and Morrais, 2018; Oghuvwu and Orakwue, 2019), the relationship between the number of KAMs and an audit fee was proved. Therefore, it was confirmed for the companies of the research sample that the higher remuneration of the auditing company causes the more accurate process of the audit and the disclosure of the higher number of key matters. However, it should be mentioned that our study, contrary to the quoted research, was conducted on the companies doing business in one chosen branch. It should be stressed that there were contradictory findings to the expectations in the part of the studies conducted earlier. The results of the research by Ferreira and Morais (2019) demonstrated that the higher the auditor's fees in relation to total assets, the lower the number of KAMs.

It was not confirmed that the higher number of KAMs is disclosed by the statutory auditors for the entities with the diverse structure, resulting from the higher number of the reported operating segments. Also, no relationship was found between the number of KAMs and the statutory auditor's category. The belief is often found in the literature, according to which the auditing companies belonging to BIG4 provide better quality audits (Francis and Yu, 2009; Krishnan, 2003). In the authors' opinion, the main reason for such a belief is a high level of standardisation of the audit procedures and the great experience of the leading auditing companies in the audit of the financial statements of the listed companies. The conclusion that the statutory auditor from BIG4 will present a higher number of KAMs than in the case of the audit conducted by smaller auditing entities is unjustified. The dependence between the number of KAMs and the strength of reporting and auditing standards was not found. It does not allow to confirm the mentioned justification of the increase in precision of the audit process and the identification of the higher number of problem areas in the countries for which this indicator takes higher values.

In the case of the control variables such as an indicator of the return of equity ROE, pre-tax gain or loss, and a solvency ratio, no significant dependences with the number of KAMs is an expected result by the authors. This confirms the conclusions from other studies, according to which "The general conclusion, which can be drawn, is that association between the company's performance measured by profitability, liquidity (...) and the number of disclosed KAMs does not exist" (Karmańska, 2020).

The authors are aware of the research limitations, resulting from a small, but comparable with the previous studies, research sample and notice a need to carry out the next research, which will be connected with the more thorough analysis of the range and the type of the disclosed key audit matters and the applied control procedures in this area in the division into the size of companies and branches. 
In our opinion, the empirical research leading to the identification of the determinants influencing the number of KAMs noticed by the statutory auditors indicate the further direction of research, which will definitely be developed by the authors. It should be expected that due to the increase in available empirical material in the form of audit reports for next years, it will be possible to undertake research aiming at testing repeatability of the reported KAMs year by year and standardisation of their descriptions.

It is possible that the descriptions of the key audit matters reported by statutory auditors every year in the audit reports will become repeatable and standardised. It will lead to a decrease in their usefulness and the informative value. Therefore, there is still a current view, according to which professional organisations should strive for next modifications of standards, aiming at the further limitation of an audit expectation gap (Akinbuli, 2010). The statutory auditor, formulating the description of key audit matters, should also realise that it is directed to the recipients of the financial statement and in order to provide an appropriate receipt of the disclosures done, proper diligence should be retained. The appropriate suggestions in that regard result from the IAS 701. It is recommended that language used in the description (the IAS $701 \S$ A47) should not suggest that the case should not have been solved appropriately by the statutory auditor while formulating an opinion on a financial statement and he referred the case directly to the individual circumstances of an entity, but he avoided a general or standard language. Meeting the recommendations as mentioned above should lead to understanding by stakeholders of both the meaning of individual KAMs in the context of an audit of a financial statement as a whole and connections between the KAMs and other elements of a statutory auditor's report, including the opinion.

We also anticipate that more and more audits will be undertaken to define an informative value of the KAM disclosures for recipients of financial statements, especially for potential investors and the influence of these disclosures on taken decisions by them. The trial to answer the question of how the statutory auditors establish the KAMs and how their selection influences further procedures of the audit of financial statements can also be mentioned as an interesting research trend.

The directions of research mentioned by us have already gradually been taken in the international literature. The relations between the disclosures of the KAMs and the investors' decisions are studied, measured by a high trade volume of shares of the studied companies. The research results indicate that this relation is significant, which suggests that these disclosures have an informative value for the investors (Altawalbeh and Alhayaja, 2019). What is more, experimental research confirms that the investors who receive an audit report including a list of key audit matters change their investment decisions more often than the investors who receive a statutory auditor's standard report (Christensen, Glover and Wolfe, 2014). Having read a statutory auditor's report, including disclosures of key audit matters, the participants of the experiment pay less attention to other parts of a financial statement (Sirois, Bedard and Bera, 2018). The analysis of the changes to the KAMs reported in the statutory auditors' reports, auditing the Polish listed companies for 2019 in comparison to 2018 allowed to verify the research hypotheses statistically, according to which the number (1) and the type (2) of the reported key audit matters do not change significantly year by year. The verification of the first hypothesis was negative, and the second one partly positive (Warzocha and Bujak, 2020).

Furthermore, the influence of taking key audit matters on a statutory auditor's work into consideration and the research results are analysed. The results indicate that the statutory auditors present a significantly less sceptical opinion while having to establish key matters than while not having such an obligation (RatzingerSakel and Theis, 2019). It was also proved that if a given area of estimation is taken into account as a key matter, a sum of corrections concerning this area suggested by the statutory auditor is lower (Asbahr and Ruhnke, 2017). In the authors' opinion, the practice of reporting KAMs will be a constant trend of theoretical considerations and undertaken empirical research in the international dimension.

Reporting KAMs may result in an increase in the awareness of entity management with reference to the process of an audit of financial statements. It indicates the areas especially exposed to risk and gives a possibility to strengthen communication between a statutory auditor and the management of a studied entity. Then, taking action in order to formulate the description of KAMs so that a problem of their repeatability and standardisation would be eliminated will be essential for statutory auditors. There is a risk that the informative value of the new form of an audit report after its initial positive receipt will decrease in connection with the invariability of the presented disclosures year by year. It can also lead to stakeholders' suspicion that an audit of a financial statement is deprived of an individual approach and concentrated on the permanent areas while others are not a subject of the statutory auditor's in-depth analysis.

As it was mentioned, the mining industry is a specific sector of the economy. Mining, gas engineering, power engineering or activity supporting them depend on available capital and technologies, the lack of which may be a barrier in development (Rogoziński, 2000). One of the determinants of intensification of the mining activity is also an issue of changes in the local and regional development. The development of the mining industry presents many changes in the social and spatial character. The topic discussed in the article refers to the mining industry in the context which is vital to entrepreneurs. However, the other side connected with the mining expansion cannot be forgotten. It regards the local community as they are the nearest to investments 
connected with the mining industry, but also the regional one. Deciding on investments in mining, gas engineering, mining of mineral ores, etc., one should be prepared for undertaking a topic of changes to the spatial planning, which will be created as a consequence of these actions. Space management in the appropriate way is to contribute to achieving a certain development objective. In some situations, it can also include processes of the spatial and social revitalisation of some areas, management of industrial areas or actions for reclamation of devastating natural areas (Karwińska, 2008). The problem of social acceptance results from limitations that the mining industry will cause. On the other hand, an agreement to the mining activity can be partly conditioned with the contribution which an enterprise will contribute to the development of the local community. There is also an issue of creating mutual relations between the parties and an ability to develop a favourable solution for everybody (Martinez and Franks, 2014; Kemp, 2010).

\section{Conclusions}

This study contributes to expanding the literature on an audit expectation gap and Key Audit Matters. The main objective of the study was to identify the determinants of the number of KAMs disclosed by the statutory auditors of the companies of the mining branch. This objective was achieved. The demonstrated research results allow stating the relationship between the number of KAMs and the size of the entity understood as the scale of activity expressed with the achieved incomes and an amount of an audit fee. The most frequent categories of KAMs in the studied companies of the mining branch include: investments in related entities, property and tangible assets, provisions and contingencies. The set of the most often used types of KAMs, differing from the results of the previous analyses, confirms the need to conduct the study taking the belonging of a company to a branch into consideration.

The increase in the informative value of audit reports, resulting from the implementation of the IAS 701 standard in the practice of an audit of financial statements should, according to the authors, be evaluated positively as a need to fulfil stakeholders' expectations - intended users of financial statements. In the authors' opinion, the changes concerning the form of an audit report were partly taken into consideration owing to the previously formulated needs of its recipients and can contribute to the better understanding of key issues which, according to a statutory auditor, were the most important in the studied period. The analysis of the disclosed KAMs for the presented research sample of the companies of the mining sector allows to state that the statutory auditors present the justification of the choice of the given area of risk in details, which can become the basis to understand the property and financial condition and the results of a given enterprise together with the risk of significant distortions.

According to the authors, the obligation to disclose key audit matters, in spite of the general positive evaluation, is not able to fill an audit expectation gap completely. The stakeholders should be expected to understand that the process of an audit of a financial statement is conducted taking a materiality level into account, and a statutory auditor is not able to detect all incorrectness in the audited entity. The disclosures of KAMs made will not substitute the full insight into the working papers created by a statutory auditor. Nonetheless, the detailed description of these matters together with the information on the applied further procedures of an audit, according to a statutory auditor, of the essential areas, allows looking at the process of an audit of financial statements in more detail. It also provides a possibility to list and analyse the KAMs disclosed in audit reports of listed companies that are given to the public.

\section{References}

ACCA (2018). Key audit matters: unlocking the secrets of the audit, https://graduate.accaglobal.com/content/dam/ACCA_Global/professional-insights/Key-audit-matters/pi-key-audit-matters.pdf, date 30.06.2020

Accountancy Europe (2018). Auditor reporting of Key Audit Matters in the European Banking Sector, Analysis and good practice examples, Survey results, the Accountancy Europe, (2018), https://www.accountancyeurope.eu/wp-content/uploads/Accountancy_Europe_KAMs_2018.pdf, date 30.06.2020

Akinbuli S. (2010). The effect of audit expectation gap on the work of auditors, the profession and users of financial information, The Nigerian Accountants, no. 43 (4).

Aljaaidi K. (2009). Reviewing the Audit Expectation Gap Literature from 1974 to 2007, International Postgraduate Business Journal, no. 1 (1).

Altawalbeh M. A. F. and Alhayaja M. E. S. (2019). The Investors Reaction to the Diclosures of Key Audit Matters: Empirical Evidence from Jordan, International Business Research, Canadian Center of Science and Education, vol 12(3).

Asbahr K. and Ruhnke K. (2017). Real Effect of Reporting Key Audit Matters on Auditor's Judgement of Accounting Estimates, SSRN Electronic Journal. 
Bedard J., Hoitash U. and Hoitash, R. (2008). Audit pricing and internal control disclosures among nonaccelerated filers. Research in Accounting Regulation, vol. 20.

Christensen B. E., Glover S. M. and Wolfe C.J. (2014). Do Critical Audit Matter Paragraphs in the Audit Report Change Nonprofessional Investors' Decision to Invest? Auditing: A Journal of Practice \& Theory, November 2014, Vol. 33, No. 4.

Deloitte (2018), The new auditor's report Study of first year of application in Italy by listed companies, https://www2.deloitte.com/content/dam/Deloitte/it/Documents/audit/Deloitte_NewAuditorReport.pdf, date 30.06 .2020

Ebimobowei A. (2010). An evaluation of audit expectation gap: issues and challenges, Department of Business Education Bayelsa State College of Education Okpoama, International Journal of Economic Development Research and Investment, 1 (2-3).

European Parliament. (2014). Regulation (EU) No. 537/2014 of the European Parliament and of the Council of 16 April 2014 on specific requirements regarding statutory audit of public-interest entities and repealing Commission Decision 2005/909/EC.

Ferreira C. and Morais A. I. (2019). Analysis of the relationship between company characteristics and key audit matters disclosed, Revista Contabilidade \& Financas, vol. 31, no. 83.

Francis J. and Yu M. (2009). Big 4 office size and audit quality. The Accounting Review, 84(5).

Ghosh S. (2011). Firm ownership type, earnings management and auditor relationships: evidence from India, Managerial Auditing Journal, vol. 26, issue 4.

Goodwin-Stewart J. and Kent P. (2006). The relation between external audit fees, audit committee characteristics and internal audit. Accounting and Finance, 46(3).

Gupta K. (2005). Contemporary Auditing, Tata McGraw Hill, New Delhi.

Iwanowicz B. (2019). Kluczowe sprawy audytu w sprawozdaniach z badania wybranych spółek giełdowych, Theoretical Journal of Accounting, vol. 105 (161).

Iwanowicz T. (2019). Identyfikacja ryzyka istotnego zniekształcenia na podstawie kluczowych spraw badania według Międzynarodowego Standardu Badania 701, Theoretical Journal of Accounting, vol. 105 (161).

ISA 701 (2015). International Standard on Auditing 701, "Communicating Key Audit Matters in the Independent Auditor's Report", International Auditing and Assurance Standards Board.

Karmańska A. (2020) The Determinants of Key Audit Matters in Building Companies Listed in Poland [in:] Krasodomska J., Chłapek K. and Krajewska S. (ed.) Accounting, Reporting and Auditing: Meeting the Needs of Information Preparers and Users, Difin, Warsaw.

Karwińska A. (2008), Gospodarka przestrzenna. Uwarunkowania społeczno-kulturowe, PWN, Warszawa.

Kemp D. (2010). Mining and Community Development: Problems and Possibilities of Local-level Practice. Community Development Journal. 45(2).

Kitiwong W. and Srijunpetch S. (2019). Cultural Influences on the Disclosures of Key Audit Matters, Journal of Accounting Profession, 15 (46).

Koh H. C. and Woo E. S. (1998). The expectation gap in auditing, Managerial Auditing Journal, 13(3).

KPMG (2017). Key Audit Matters Auditor's report snapshot, https://home.kpmg/au/en/home/insights/2017/09/key-audit-matters-auditor-report-20-september2017.html, date: 30.06 .2020

Krishnan, G. (2003). Does Big 6 auditor industry expertise constrain earnings management? Accounting Horizons, 17(1).

Kutera M. (2019), Kluczowe kwestie badania - nowy element w raportowaniu biegłych rewidentów, Theoretical Journal of Accounting, tom 101 (157).

Lee T.H., Ali A. and Gloeck J. (2009). The Audit Expectation Gap in Malaysia: An Investigation into its Causes and Remedies, South African Journal of Accountability and Auditing Research, no. 9.

Loew E. and Mollenhauer T. (2019). An Empirical Analysis of Key Audit Matters in the Financial Industry, European Banking Institute Working Paper Series, no 4.

Markanian G. and Parbonetti A. (2007). Firm complexity and board of director composition. Corporate Governance: an international review, 15(6).

Martinez C. and Franks D.M. (2014). Does mining company-sponsored community development influence social licence to operate? Evidence from private and state-owned companies in Chile, Impact Assessment and Project Appraisal, 32:4.

Mayhew, B. W. Schatzberg, J. W. and Sevcik, G. R. (2001). The effect of accounting uncertainty and auditor reputation on auditor objectivity. Auditing: A Journal of Practice \& Theory, vol. 20.

Natkaniec K. (2020). Identification of Key Audit Matters and Verfication Procedures on the Example of Construction Industry Companies Listed on the Warsaw Stock Exchange [in:] K. Chłapek, S. Krajewska and P. Zieniuk (ed.), Wyzwania rewizji finansowej, Difin, Warsaw.

Oghuvwu M. E., Orakwue A. C. (2019). Determinants of Key Audit Matters, Accounting and Taxation Review, $3(3)$. 
Pfaff J. (2007). Wpływ rewizji finansowej na wiarygodność sprawozdania finansowego, University of Economics in Katowice.

Pinto I. and Morais A. I. (2019). What matters in disclosures of key audit matters: Evidence from Europe, Journal of International Financial Management and Accounting, vol. 3, issue 2.

Prawitt, D. F., Sharp, N. Y. and Wood, D. A. (2011). Reconciling archival and experimental research: Does internal audit contribution affect the external audit fee? Behavioral Research in Accounting, 23(2).

Ratzinger-Sakel N. V. S. and Theis J. (2019). Does Considering Key Audit Matters Affect Auditor Judgement Performance?, Corporate Ownership \& Control, vol. 17, issue 1.

Rogoziński K. (2000), Usługi rynkowe, Akadamia Ekonomiczna w Poznaniu, Poznań.

Saeidi F. (2012), Audit expectations gap and corporate fraud: Empirical evidence from Iran, African Journal of Business Management, 6 (23).

Salehi M. and Rostami V. (2009). Audit Expectation Gap: International Evidence, International Journal of Academic Research, 1(1).

Schwab K. (ed) (2018), The Global Competitivesness Report, World Economic Forum, Switzerland.

Sierra-Garcia L., Gambetta N., Garcia-Benau M. A. and Orta-Perez M. (2019), Understanding the determinants of the magnitude of entity-level risk and account-level risk key audit matters: The case of the United Kingdom, The British Accounting Review, vol. 51.

Sirois L. P., Bédard J., and Bera P. (2018). The Informational Value of Key Audit Matters in the Auditor's Report: Evidence from an Eye-Tracking Study, Accounting Horizons, vol. 32, no. 2.

Tusek B. and Jezovita A. (2018), The Key Audit Matters as an Element of the Independent Auditor's Report - a Booster to the Corporate Governance, Intereulaweast, vol. V (2) 201.

Warzocha G. and Bujak K. (2020). Key Audit Matters in Audiotr's Reports [in:] Krasodomska J., Chłapek K. and Krajewska S. (ed.) Accounting, Reporting and Auditing: Meeting the Needs of Information Preparers and Users, Difin, Warsaw.

Yang R., Yu Y., Liu M. and Wu K. (2018). Corporate risk disclosure and audit fee: A text mining approach. European Accounting Review, 27(3). 